\title{
Bibliometric analysis of sustainable agriculture on human rights governance approach: concept of sustainability on human rights governance
}

\author{
Nita Tri Oktaviani, Eko Priyo Purnomo*, Lubna Salsabila, and Aqil Teguh Fathani \\ Department of Government Affairs and Administration, Jusuf Kalla School of Government, \\ Universitas Muhammadiyah Yogyakarta, 55183, Indonesia
}

\begin{abstract}
This study aims to examine social justice and human rights from the government's perspective to promote Sustainable Development as well as from an agricultural perspective. This research method is qualitative research with literature study. literature study is carried out to find out various distances or findings that have not been found in previous research as a comparison in conducting current research. The literature findings show that some of the main topics appear most frequently based on data from Scopus, vosviewer and Nvivo12 plus. The results of this study of Global Governance of Human Rights with a total of 78 documents, but it is not comparable to the reality on the ground; namely, there are still many cases of human rights, racism and conflicts between black and white groups. Second, Global Human Rights Governance has an important role in the methodology of human rights analysis. From the perspective of global governance, the concept of sustainability is correlated with the idea of human rights such as the emergence of development in rural communities' agricultural land which causes changes in their livelihoods as farmers which affect the economy and the surrounding environment. In the concept of SDGs, justice is one of the concepts that is of concern to the government that must be developed through a governance approach
\end{abstract}

\section{Introduction}

The role of non-state actors in the development of the global political constellation raises the issue of civil society in global human rights governance. Global human rights governance can be seen from several social aspects such as economic aspects. Shifting economic policies have led to discussions about nationalist resources [1]. Debates about human rights also participate in supporting and maintaining resources [2]. Globally, human rights to health also play an active role. In 2020, the life of the world after the PPB (United Nations), all international human rights can be accepted by several countries and there are many institutions established globally to reduce the impact of human rights [3].

Human rights have a broad scope. Various human rights polemics have also occurred globally. Global governance can be seen from the resources related to human rights.

*Corresponding author: eko@umy.ac.id 
Government in the form of land is often associated with the formation of the state and the emergence of a national legal system that gave birth to capitalist products [4]. Taking discriminatory action or non-compensation results in international litigation based on aspects of human rights [5]. Views regarding human rights can occur because of violent incidents with global consequences. Acceptance of human rights violations [6] was found to be weak due to the emergence of the effectiveness of humanitarian law in the international realm from time to time.

The need for food plays a role in human rights. The existence of a sustainable agricultural system has the aim of improving the quality of life of the community [7]. In the short term it might help land productivity, but in the long term it could be environmental destruction itself, such as the transfer of agricultural land to the construction of the NYIA airport which occurred in Kulon Progo. This, of course, indirectly robs people of their rights. It is not easy for them to find new agricultural land and plantations, moreover, the majority of villagers work as farmers. Developments that involve the environment certainly have consequences in the form of changes in community activities [8]

This study presents the trends of global human rights governance in the world using bibliometrics. Bibliometric or scientometric analysis can be said to be a useful research field in the field of analysis using literature in certain fields and providing direction and motivation for future research work [9]. To find out trends, subjects and research objectives are presented in the form of bibliometric analysis [10]. Selection of bibliometric software aims to assist in the selection, storage, recording and presentation of research results [11].

\section{Literature review}

\subsection{Concept of sustainability}

The concept of sustainability cannot be separated from various problems, both in terms of environmental and social issues. In an effort to overcome social problems in a sustainable manner, it is always related to social, humanitarian and environmental problems [12]. In identifying social problems in a sustainable manner, it is carried out operationally which causes the aspects contained in the concept of sustainability to disappear [13]. One of the important problems faced in sustainability is maintaining environmental sustainability [14]. One of the development problems related to environmental sustainability is development based on the economy of natural resources. If the economic development does not consider the capacity of natural resources and the surrounding environment, it will cause new problems [15]. Exploring natural resources for sustainable development must also be adjusted to the needs of the community so that the right to fulfil basic needs for humans is also fulfilled [16]. It is important that the needs and rights of the community be increased in the concept of sustainability. In addition, the quality of people's lives is in the form of guaranteed welfare for the present and the future [16]. Assumptions regarding sustainability must have a long-term impact. Various contributions and implications must be known for their causes and effects[17,18]. Equity and social justice have both social, economic and environmental roles so that poverty does not widen and sustainable development must be considered for future generations[19].

Sustainability is often linked in the context of development. The meaning of the word sustainability is a continuous process in order to maintain quality so that there is no decline [20]. Land protection is part of the spatial planning area must have a plan. Agricultural areas are food lands that need to be protected, be it rural areas, district areas and urban areas. Based on the regulations, the community plays a role in planning and protecting agricultural land as stated in article 67, namely "(1) community participates in protecting the area and land for sustainable food agriculture. (2) community participation as referred to in paragraph (1) can 
be carried out individually and/or in groups. (3) the participation as referred to in paragraph (1) shall be carried out in stages planning, development, study, supervision, farmer empowerment and/or financing [21]

\subsection{Human right governance}

Human rights are rights that cannot be revoked or eliminated by anyone where these rights are guaranteed by the State or the government. Therefore, every country has absolute rules related to human rights [22]. In a constitutional state, through the 1945 constitution of the Republic of Indonesia stipulates that Indonesia is a legal state, which has been regulated in Article 1 paragraph (1) of the 1945 Constitution of the Republic of Indonesia [23]. As a state of law, in defending and protecting society, human rights become the foundation of national law [24]. In general, human rights are dignity for real recognition [25]. Which means that human rights must be understood in their implementation [26]. In social life, everyone in fulfilling their rights must be done together [22]. In addition, laws made are aimed at benefiting the interests of every citizen, not for some people who have power [27]. Governance can be said to be good if human rights can be upheld. To strengthen the protection of human rights, it is necessary to have the maximum involvement and participation of the public in government, especially for groups and in policy making [28]. A rule of law such as the Republic of Indonesia has guarantees for both freedom of religion and protection of human rights [29]. Thus, laws and regulations or policies can guarantee protection of human rights [30].

\section{Method}

This research uses this method, qualitative research with literature review[31,32]. The literature review was carried out as a comparison of previous findings that had not been found by previous researchers. In this study, a literature review is used to determine the development of the study of Global Governance of Human Rights. This research was conducted to determine two analyzes. First, digging up information about the dynamics of research on Global Governance of Human Rights. Second, to find out where the most dominant research on Global Governance of Human Rights was conducted. To achieve the research objectives, literature review is used as the right choice.

The data source comes from the article database in Scopus. Data disaggregation was carried out in the last 5 years by selecting the type of document, namely journal articles with high citation and limiting the time of collection with vulnerability from 2017 to 2021 so that 297 articles were obtained [11]. Journal article data is then downloaded from the Scopus data base with the format type RIS which is then imported to Vosviewer for analysis [11]. Then data is RIS imported with a create map to find out the bibliographic data. The data can then be displayed through the network, overlay, and density visualization so that we can know the clustering of the data obtained. In addition, researchers also use the Auto Code feature in the Nvivo 12 Plus Software to describe the categorization, relations and presentation of themes in the development of research on Global Governance of Human Rights [33].

\section{Discussion}

The trend in the development of research on Global Governance of Human Rights has a number every year so that it has a fluctuating number where there is a graph of increase and decrease in the last five years. Studies related to "Global Governance of Human Rights" in social science have developed every year. Based on the table above in the last five years, the 
trend shows the fluctuating number of publications each year. The results of the analysis show that the highest number of publications is in 2020 with a percentage $(30 \%)$ and the number of publications is 88 documents. In 2019 and 2018 it had the second highest percentage by numbers (24\%). Publication every year shows an insignificant increasing trend, such as in 2019 and 2018 the percentage of the number of publications did not experience an increase. Then the number of publications in 2017 was $(21 \%)$ and the last order was $2021(1 \%)$ with 4 documents, but in the early January 2021 period.

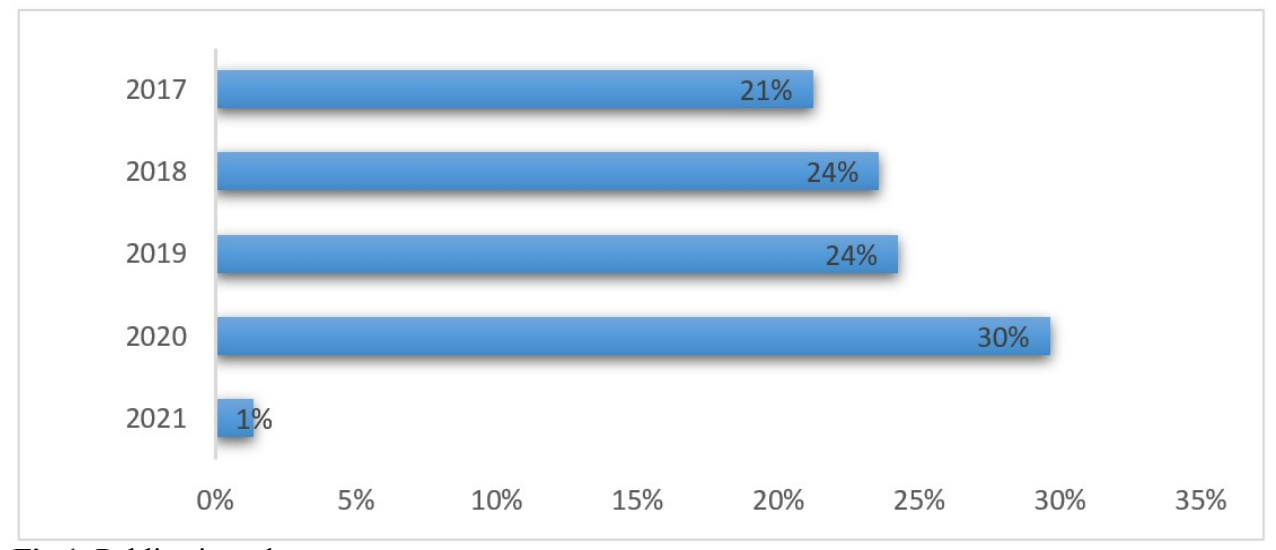

Fig 1. Publications documents

Source: Scopus 2021

A total of 297 scientific articles / publications are divided into two types of documents (articles and reviews). The results of the analysis of the determined data indicated a significant comparison between the types of documents. Publication of documents in the Scopus database on Global Human Rights Governance was found (85\% types of article documents and (15\%) reviews.

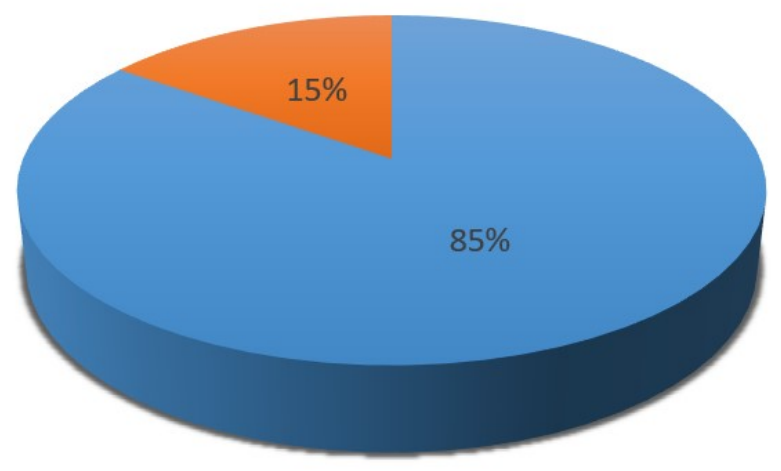

Fig 2. Number of publications in blue color (documents) and orange color (articles)

Source: Scopus 2021

The distribution of countries figure 3 is then seen from the aspect of affiliation which can show institutions / organizations that have contributed to the development of research on Global Governance of Human Rights. Based on the results of the analysis, the University of Toronto obtained a percentage (13\%) and was ranked as the highest number one. University Of Sydney occupies the second highest percentage of acquisitions with the same number, namely (13\%). The third-highest affiliated institute of Georgetown University and the 
Primakov National Research Institute for World Economics and International Relations, the Russian Academy of Sciences received a percentage of the total (11\%). The fifth to the top ten ranks have the same number of publications and the percentage as the number $(9 \%)$.

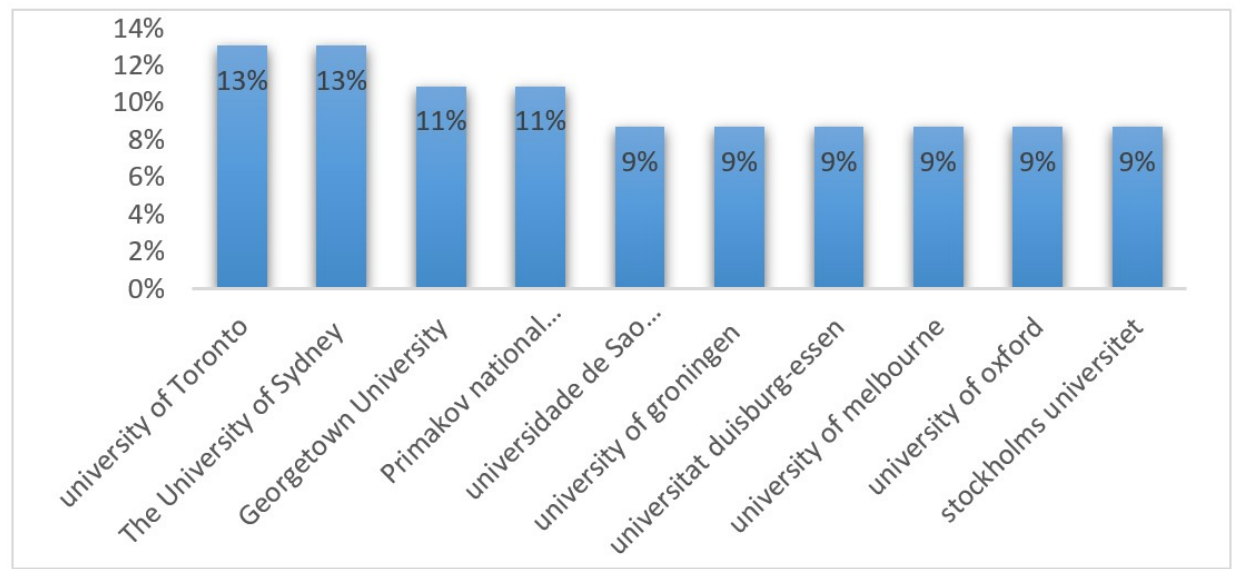

Fig 3. Number of publications by university

Source: Scopus 2021

The contribution of articles on the field of global human rights governance in the Scopus database consists of several related countries. The table below shows the country classification based on the number of articles published. Total number of articles published on Global Human Rights Governance. This condition can be seen from the percentage which reaches $(31 \%)$.

Comparison of development trends over the last five years in the table above, there is still dominance from one country. The United States has the highest percentage by numbers (31\%), then Great Britain has the second highest percentage by numbers (17\%). Countries that occupy the top three positions have a percentage by the number $(11 \%)$. Then Germany, the Netherlands, Italy, Brazil, China, and the Russian Federation have relatively the same percentage difference (1\%) and make the Russian Federation occupy the top ten with the total percentage $(3 \%)$.

The few authors focus on research on Global Governance of Human Rights. The results of the analysis of Scopus data for the last five years show only one single author. In addition, the contribution of the author who focuses on Global Governance of Human Rights is very small in terms of the distribution of each individual.

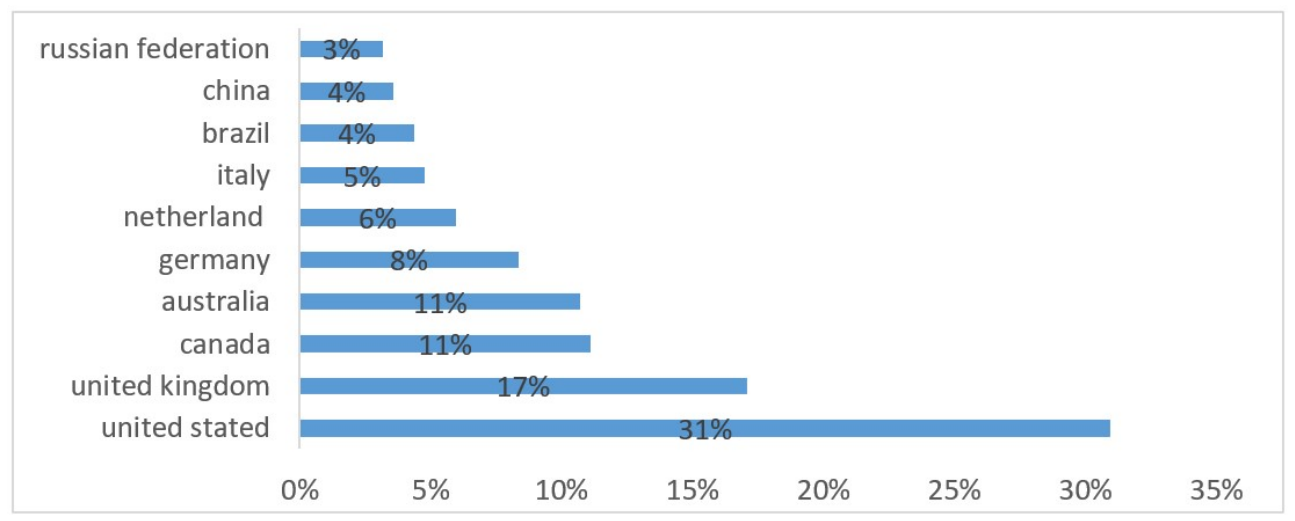

Fig 4. The country that published the Global Government of Human Rights

Source: Scopus 2021 
Piper, N., author with the highest number of publications with a percentage (14\%) and 3 documents published. In second place the authors Augenstein, D., has the number of publications in 1 document Piper, N. with percentage (10\%). Then for the third to tenth order, there are the same number of documents, namely 2 documents with a percentage $(10 \%)$, namely Ballor, GA, Bernstein, S., Denny, DMT, McKeon, N., Petersmann, EU, Reinold, T., Rother, S., Suh, S.
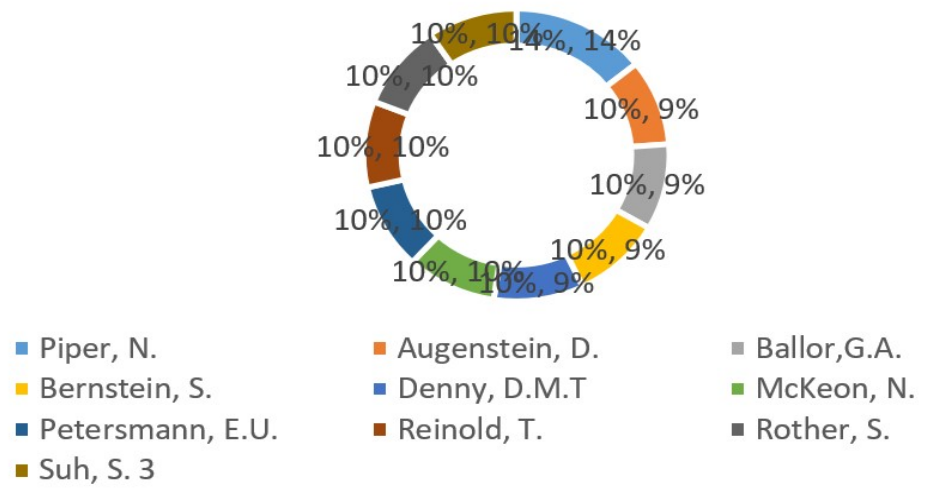

Fig 5. Author Ranking Based on Number of Publication Documents Source: Scopus 2021

\subsection{Network between Topics Keywords "Global Governance of Human Rights"}

The inter-topic network of 297 documents obtained from the Scopus database was carried out by bibliometric analysis by creating a Vosviewer network visualization, overlay, and density. Nodes and edges belong to the bibliometric network. Nodes are represented by circles in the form of publications, journals or keywords, whereas edge shows the relationship between pairs of nodes. Not only does it show the relationship between two nodes, the edge is also the strength of the relationship represented by the distance. The closer the distance between one node and another indicates the high relationship between these nodes [34]. Visualization of the Global Governance of Human Right keyword network can be seen from the results of the Vosviewer analysis as shown in the following figure.

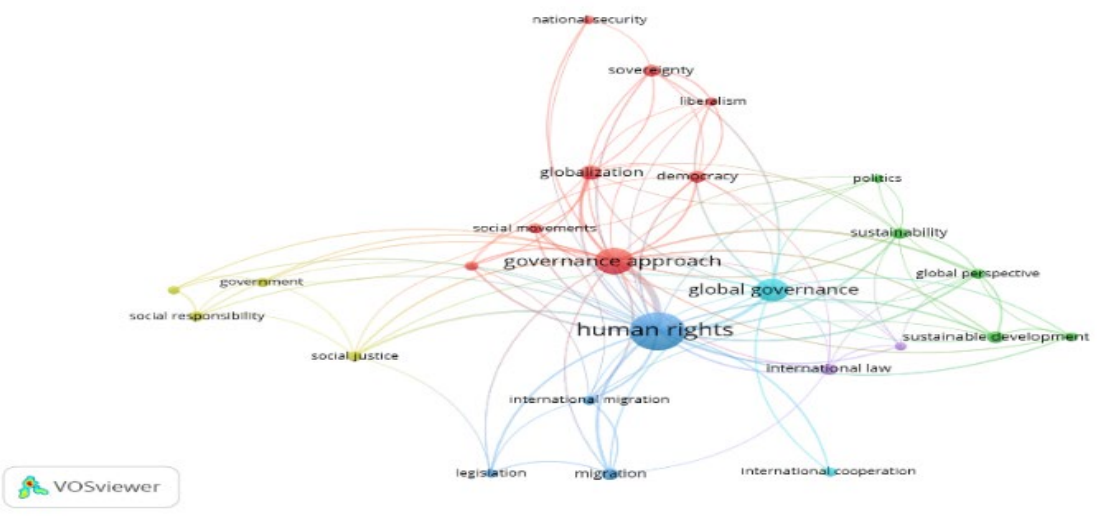

Fig 6. Network visualization

Source: VOSviewer 2021 
In the picture shown there are keywords that often appear and the color indicates the group. In obtaining a detailed picture, image mapping is carried out while clustering is used as an overview and general insight for bibliometric grouping [34]. Each circle represents a keyword or term that occurs frequently. The size of the circle depends on the number of issues related to the terms in the document title. The bigger circle size, the more documents that are relevant to that keyword or term.

Figure 6 shows that the large keyword node size is Human Right. In addition, other keywords that have relevance to human rights are governance approaches, global governance, international migration, migration and so on. The difference in the color of the connecting lines in the image above shows the existence of a cluster relationship in the theme of global governance. Other keywords are divided into 6 clusters, where each keyword has a relationship in its visualization. The details of the cluster keywords and items are in the following table. The clusters show that a term has connected to one another. In the perspective of global governance, the concept of sustainability is correlated with the concept of human rights. These results are related to the SDGS concept which involves aspects of justice.

The Human Rights keyword ranks first with 96 events and 220 total link strength. Followed by the second rank, namely governance approach with 47 and 162 . Then global governance with 35 and 79 ranks third and other keywords. With their huge emergence and total linking power, they were able to forge strong linkages between keywords in Human Rights. This strong relationship indicates that human rights issues are never exhausted to be discussed and issues related to human rights continue to increase. Meanwhile, social justice ranks eleventh, which means that in upholding justice, not all people feel this. There are still gaps that mean that not all human rights problems can be upheld through justice [35].

Apart from network visualizations, overlay visualizations can also be displayed. The color of the nodes can indicate the year the article containing that keyword was published. The darker the color on the node, the longer the topic is discussed in the study, and vice versa, the brighter the color on the node, the more actual topics in a study. The overlay visualization can be seen in the following image.

fos vosviewer

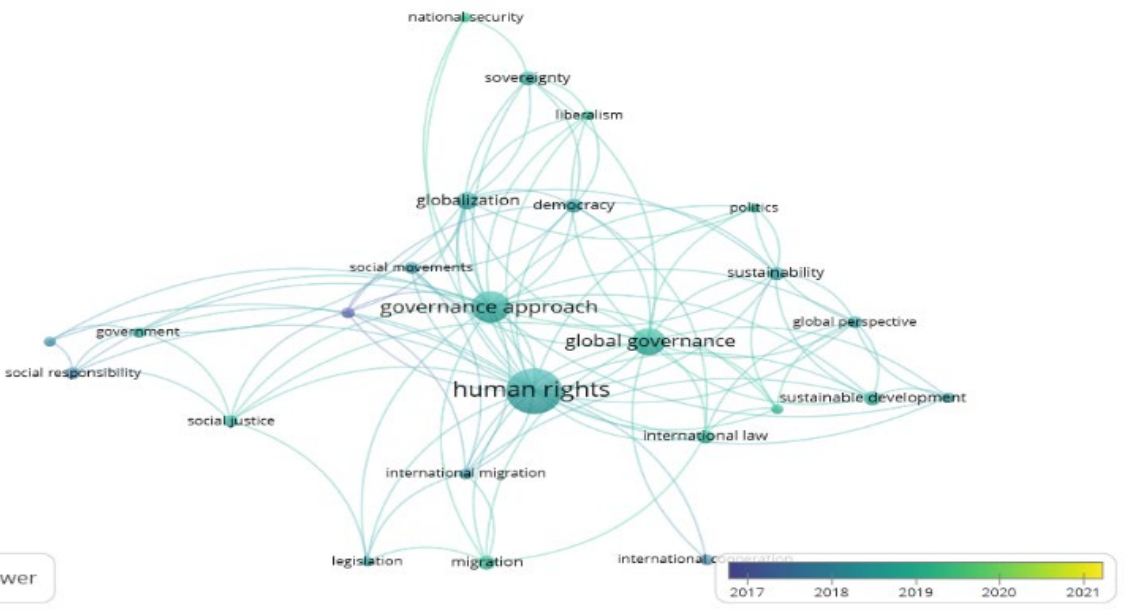

Fig 7. Overlay visualization

Source: VOSviewer 2021

Topics related to civil society, social movements, social justice, international migration, globalization, democracy and other nodes in purplish blue are topics discussed in 2017 to 2018. On the other hand, Vosviewer also uses a red base color red, green, blue (RGB) from 
each visualization produced [34]. This visualization, called density, is used to see the level of density or at least the number of topics being studied. The redder a knot, the more research that addresses a particular topic, conversely the greener the knot, the less research on that topic. Based on this net, human right is related to the two most intersecting points, namely the governance approach and global government. This means that human rights are also related to governance in dealing with problems that exist in society so that it can show that the government can work well in handling cases in the form of human rights.

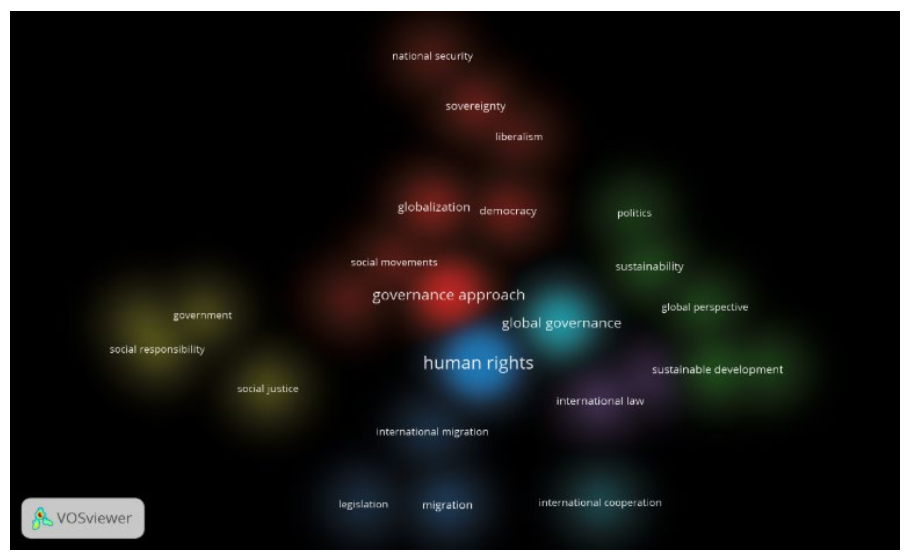

Fig 8. Density visualization

Source: VOSviewer 2021

Based on Figure 8, the saturation level shown from the number of keywords that often appear can be seen in the blue color around the human rights label. In the implementation, human rights values must be handled by the government and not limited to the central government [36]. Human rights have a universal scope in which all rights have international recognition, including respect and protection for people with special needs. Every country including Indonesia has regulations regarding justice and human rights [23]. However, in the implementation of human rights, there are still imbalances in terms of social, environmental and economic conditions, so it is an interesting topic to be studied widely. Next is the topic of social justice which always happens. One of the real forms of justice is recognition and rights for the community. Justice must be equalized without discriminating against ethnicity, religion or social class. The achievement of justice is often seen as reducing inequality [37]. The government is responsible for all forms of human rights to its people. If human rights and social justice are guaranteed, the rules and policies made by the government can be said to be successful. This last topic has not been researched much. This shows that the opportunity to conduct research on this latter topic is still very broad, especially the topic of social justice. Many researchers use this theme, but problems regarding social justice are in fact inversely proportional to the applicable penalties so that all problems regarding social justice are related to law [38]. It's just that the law applies to people looking upwards, not middle to lower class people. Even though there are still many social justice issues that occur in various countries that are interesting to discuss and have not been resolved.

\subsection{Categorization of human rights global governance themes}

Based on the analysis on the cluster using Nvivo 12 plus sourced from 297 Scopus indexed articles, there are 6 main clusters in the study of global human rights governance, namely Global, Governance, rights, reference, political and library. Furthermore, the results of the 
research theme category indicate that this research on governance discusses a lot about the six themes.

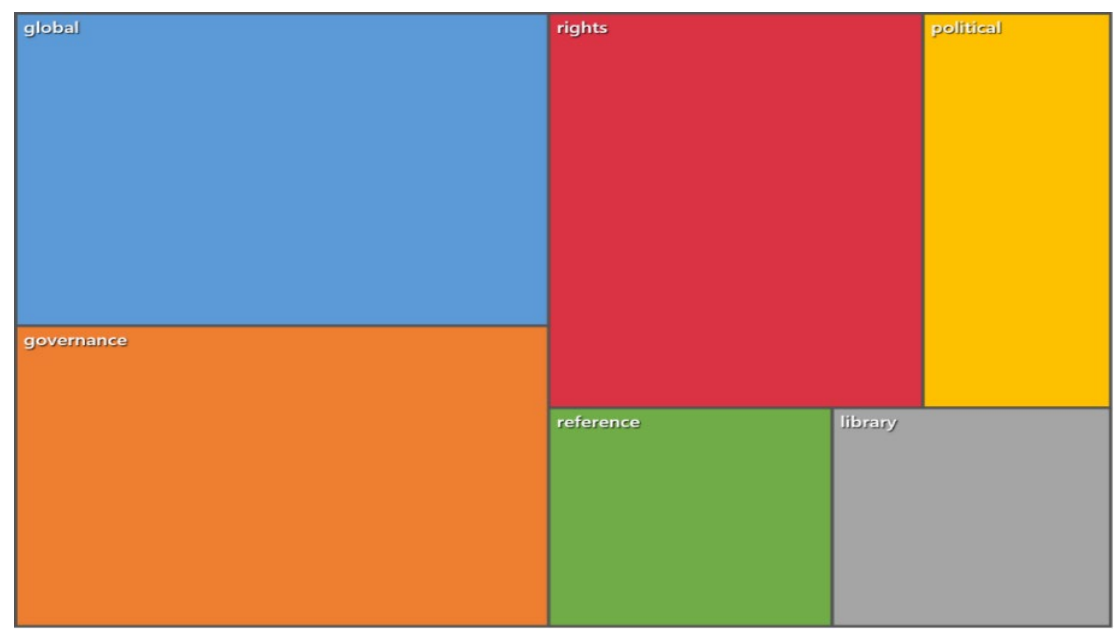

Fig. 9. Category theme

Source: Nvivo12

The theme of this research discusses the global scope of human rights that guarantees the life and rights of all people. In general, the sustainability of human rights occurs continuously. It cannot be denied that several cases of human rights violations to date are still incomplete [39]. The government also plays a role in the sustainability of human rights. For the Republic of Indonesia which adheres to a democratic system, community rights and justice have a profound impact on the quality of life of the people. The existence of a binding law is a guarantee for the sustainability of human life in the future [40]. However, various cases concerning human rights cannot be resolved properly. Even though it is clearly written in the fifth verse of Pancasila that "social justice for all Indonesian people". It's just that the implementation has not been implemented optimally. Inequality between the rich and the poor is also a human right. A government that has a policy of protecting its people must act fairly. If the issue of human rights is not handled in a sustainable manner, many people from various groups will be affected. This is why the topic of human rights is in the top category [35].

The agricultural aspect in the form of land also affects human rights. Efforts to protect sustainable agricultural land are also food security for the community. Most of the food produced comes from agriculture [41]. If the transfer of agricultural land into buildings, of course, it will take away the rights of the community, especially in terms of livelihood. Regional spatial planning often does not involve the aspirations of the local community, resulting in disputes between the community and the government. This condition is one of the causes of the weak legal protection of agricultural land. In rural areas, small farmers and poor communities are limited in their movement space so that their agricultural land is very easy to change. Indirectly, their land ownership rights had to be shifted due to political interests.

Apart from that, political interests also influence the sustainability of human rights. Politics can be used as a driving force in solving problems such as economic development. The government carries out continuous development aimed at improving the economy in an area. However, the people were forcibly evicted and the pay they got was not appropriate. Even though the land that was taken over was their livelihood. This means that their land 
rights are taken without thinking about the impact that will occur in the future. Political elites should be a forum for criticism and suggestions for lower class people in achieving social justice, but the existence of political interests has an impact on human rights [42,43].

\section{Conclusions}

The development of human rights governance studies on the analysis of sustainable agriculture in the last five years has experienced fluctuating growth every year. Human rights issues must be resolved based on the laws and regulations of each country. Because both human rights in general and agricultural land rights have been regulated in law. Every citizen has the right to justice. Justice is an issue that is closely related to human rights, be it environmental, social or economic. Sustainability in terms of agriculture is adjusted to the majority of the livelihoods of the surrounding community so that they can obtain their human rights, especially for farmers who depend on agricultural products for their economic needs. If their agricultural land is replaced by development, as a result, their livelihoods will also have an impact.

Development involving community land must be correlated with future impacts such as land conversion for farmers. The government and the community must be able to discuss in advance related to land changes, so that they can obtain their respective rights. The results of the correlation and relationship analysis in seeing the renewal of the research theme can be seen from the results of the classification based on clusters. Researchers processed data on Article Scopus documents using Vosviewer, getting a comparison into 6 clusters. Analysis of sustainable agriculture has an important role in the methodology of human rights analysis.

\section{References}

1. J. C. Franco, S. Monsalve, S. M. Borras, Current Opinion in Environmental Sustainability, (2015)

2. A. Arcuri, Huk. Kebijak. Investasi Int. 2018, (2019)

3. S. Gruskin, E. J. Mills, D. Tarantola, Lancet, 370, 9585 (2007)

4. H. Jones, 39 Ilmu Huk., (2019)

5. L. Cotula, J. Int. Econ. Law, 23, 2 (2020)

6. M. Bussmann, G. Schneider, A Porous Humanitarian Shield: The Laws of War, the Red Cross, 11, 3 (2015)

7. K.A. Salikin, Sistem pertanian berkelanjutan. (Yogyakarta: Kanisius, 2003)

8. O. Soemarwoto, Ekologi, lingkungan hidup dan pembangunan. (Jakarta: Djambatan, 2001)

9. P. K. Muhuri, A. K. Shukla, A. Abraham, "Industry 4.0: A bibliometric analysis and detailed overview," [Online]. https://doi.org/10.1016/j.engappai.2018.11.007, (2019)

10. L. Alcaide-Muñoz, M. P. Rodríguez-Bolívar, M. J. Cobob, E. Herrera-Viedma, Gov. Inf. Q., 34, 3 (2017)

11. A. Perianes-Rodriguez, L. Waltman, N. J. van Eck, Journal of Informetrics, 10, 4 (2016)

12. K. Rangan, L.A. Chase, S. Karim, Strategies, 30, 4 (2017)

13. J. Bonn, I. Fisher, J. Bus. Strategy, 32, 1 (2011)

14. A. Fauzi, Ekonomi Sumber Daya Alam dan Lingkungan, Teori dan Aplikasi. (PT Gramedia Pustaka Utama, 2004)

15. A. H. Rahadian, "Strategi Pembangunan Berkelanjutan," Pros. Semin. STIAMI, III, 01 (2016)

16. Sutamihardja, Perubahan Lingkungan Global; Program Studi Pengelolaan Sumber Daya Alam dan Lingkungan, (Sekolah Pascasarjana; IPB. 2004) 
17. G. Heal, Valuing the Future Economic Theory and Sustainability. (1998)

18. E. P. Purnomo, P. B. Anand, J. W. Choi, J. Sustain. For., 37, 3 (2018)

19. A. Nurmandi, E.P. Purnomo, Int. Rev. Public Adm., 16, 2 (2011)

20. A. Sukur, Pertanian Berkelanjutan. (Malang, 2008)

21. A. Freastoni, Sirajudidin, "Politik Hukum Perlindungan Lahan Pertanian Dan Hak Asasi Petani Sebagai Instrumen Mewujudkan Ketahanan Pangan Berkelanjutan Di Indonesia," III, 2 (2016)

22. J. Asshidiqie, Serpihan Pemikir. Hukum, Media dan HAM, 2, 1 (2009)

23. R. Marbun, PADJADJARAN J. Ilmu Huk. (Journal Law), 1, 3 (2014)

24. I.G. Yuliartha, J. Law Reform, 5, 1 (2009)

25. J. Hamidi, Teori Hukum Tata Negara : A Turning Point of The State, (Jakarta; Salemba Humanika. 2012)

26. Y. Neta, "Demokrasi dan hak asasi manusia dalam konsep negara hukum."

27. J. M. Gaffar, Demokrasi Konstitusional Praktik Ketatanegaraan Indonesia Setelah Perubahan UUD 1945, Cet-1, (Jakarta: Konstitusi Press, Konstitusi. 2012)

28. U. Nations, Governance Practices for the Protection. (2007)

29. M. Wijaya, J. Advokasi, 5, 2 (2015)

30. L. Amir, M. Yarni, J. Ilmu Huk. Jambi, 5, 2 (2014)

31. A. Dewi et al., Heal. Promot. Perspect., 10, 4 (2020)

32. L. J. Moleong, Metodologi penelitian kualitatif, Cet. ke-30. (Bandung: Remaja Rosdakarya., 2012)

33. A. Edwards-Jones, J. Educ. Teach., 40, 2 (2014)

34. E.K. Aribowo, Aksara, 31, 1 (2019)

35. I. Dwisvimiar, J. Din. Huk., 11, 3 (2011)

36. E. G. Chueca, "Human rights in the city and the right to the city: Two different paradigms confronting urbanisation," Glob. Urban Justice Rise Hum. Rights Cities, (2016)

37. C. Siregar, Humaniora, 5, 1 (2014)

38. P.S. Sumaya, J. Huk. Responsif FH UNPAB, 6, 6 (2018)

39. E. Rosana, J. TAPIs, 12, 1 (2016)

40. L. Cotula, "Between Hope and Critique: Human Rights, Social Justice and Re-Imagining International Law from the Bottom Up," (2020)

41. Komisi Nasional Hak Asasi Manusia, Pengaturan dan Realisasi Pemenuhan Hak Atas Pangan. (Jakarta, 2005)

42. E. Hidayat, Asas J. Huk. dan Ekon. Islam, 8, 2 (2016)

43. E.P. Purnomo, R. Ramdani, L. Salsabila, J.W. Choi, Dev. Pract., (2020) 